\title{
ASPECTS OF ARBUSCULAR MYCORRHIZAL FUNGI IN AN ATLANTIC FOREST CHRONOSEQUENCE PARQUE ESTADUAL TURÍSTICO DO ALTO RIBEIRA (PETAR), SP.
}

\author{
Marcos P.M. Aidar ${ }^{1,2}$, Rosilaine Carrenho ${ }^{3}$, Carlos A. Joly ${ }^{4}$
}

Biota Neotropica v4 (n2) - http://www.biotaneotropica.org.br/v4n2/pt/abstract?article+BN02504022004

\author{
Date Received: $12 / 14 / 2003$ \\ Revised: 06/30/2004 \\ Accepted: 07/01/2004
}

\begin{abstract}
${ }^{1}$ Seção de Fisiologia e Bioquímica de Plantas, Instituto de Botânica, PB 4005, SP, 01061-970, São Paulo, Brasil www.fisiologiavegetal.bio.br; ${ }^{2}$ Corresponding author: maidar@uol.com.br

${ }^{3}$ Departamento de Biologia, Universidade Estadual de Maringá, Paraná, Brasil www.uem.br

${ }^{4}$ Departamento de Botânica, Universidade Estadual de Campinas, Campinas, SP, Brasil www.unicamp.br
\end{abstract}

\begin{abstract}
Mycorrhizal colonization was assessed in roots of trees within an Atlantic Forest chronosequence, located in the southeastern of São Paulo State, Brazil, inside Tourist State Park of the High Ribeira Valley (PETAR). The phytosociological survey was carried out in three adjacent areas, all on calcareous soil, which correspond to different time intervals during which they have been left abandoned following a slash-and-burn agricultural perturbation. Early Phase (EP) with 15 years; Mid Phase (MP) with 25 years; and Late Phase (LP) with more than 36 years without clear-cut. The inventory indicated a continuum of tree species substitution, which is dominated by species of Leguminosae, especially Piptadenia gonoacantha (Mart.) J.F. Macbr. (Mimosoideae) in the earlier successional phases. Mycorrhizal colonization, estimated by the occurrence of the mycorrhizal structures in the tree species roots, diminished during the season with less rain (winter), and showed no significant differences between successional phases in the wet season (summer). Rather, the mycorrhizal colonization was correlated with occurrence of the tree's successional status: being positively correlated with occurrence of pioneer species, and negatively correlated with late secondary species. Mycorrhizal colonization was also correlated negatively with soil organic matter and base saturation. Twenty five species of arbuscular mycorrhizal fungi belonging to four genera were identified. Six species were only identified to generic level. The species Glomus etunicatum Becker \& Gerd. represented 10\% of the total number of spores and occurred in all phases and seasons, while the genus Glomus represented 57\% of the total of spores found in the rhizosphere. The diversity indices evaluated for the mycohrriza community were: H' $=2.3, \mathrm{~J}^{\prime}=0.97$ and $\mathrm{R}=4.12$. These results are a contribution to the knowledge of The Atlantic Forest biodiversity and may have implications to support programs regarding rehabilitation of degraded vegetation in one of the World's most threatened Biomes.
\end{abstract}

Key words: secondary succession, Atlantic Forest, tropical calcareous soil, arbuscular mycorrhizal fungi (AMF), Piptadenia gonoacantha.

http://www.biotaneotropica.org.br 


\section{Resumo}

Foi levantada a ocorrência de colonização por micorriza nas raízes das espécies arbóreas que dirigem a sucessão secundária sobre solo calcário em uma área localizada no Parque Estadual Turístico do Alto Ribeira (PETAR), sudeste do Estado de São Paulo, Brasil. O levantamento fitossociológico foi realizado em três áreas justapostas correspondentes a diferentes idades de abandono após cultivo de subsistência sobre um solo calcário: Fase Inicial com 15 anos; Fase Intermediaria com 25 anos e Fase Tardia com mais de 36 anos sem corte raso. O inventário indicou a predominância de espécies da família das leguminosas, especialmente Piptadenia gonoacantha (Mimosoideae) nos estágios iniciais de sucessão. A ocorrência de colonização por micorriza nas raízes das espécies arbóreas decresceu ao longo da sucessão durante a estação com menos chuva (inverno). Durante o período de verão, estação mais úmida, a colonização não apresentou diferenças significativas entre as fases de sucessão. A colonização por micorriza nas raízes apresentou correlação com a ocorrência de diferentes estratégias de regeneração entre as espécies arbóreas: positivamente com o aumento de ocorrência de espécies pioneiras e negativamente com espécies secundárias tardias. A colonização apresentou também correlação negativa com o conteúdo de matéria orgânica e saturação de bases no solo. Foram identificadas 25 espécies de fungos micorrizicos arbusculares pertencentes a quatro gêneros, e seis espécies apenas foram identificadas ao nível de gênero. A espécie Glomus etunicatum Becker \& Gerd. representou $10 \%$ dos esporos encontrados na rizosfera das amostras analisadas, tendo ocorrido em todas as fases sucessionais e estações. O gênero Glomus representou 57\% do total de esporos. Os índices de diversidade para a comunidade de fungos micorrizicos indicaram os seguintes valores: $\mathrm{H}^{\prime}=2.3, \mathrm{~J}^{\prime}=0.97 \mathrm{e} \mathrm{R}=4.12$. Estes resultados são importantes contribuições para um melhor conhecimento da biodiversidade da Mata Atlântica e podem ser decisivos no sucesso de ações para a reabilitação de áreas degradadas neste que é um dos biomas mais ameaçados do planeta.

Palavras-chave: sucessão secundária, Mata Atlântica, solo calcário tropical, fungo micorrízico arbuscular (FMA),

Piptadenia gonoacantha.

http://www.biotaneotropica.org.br 


\section{INTRODUCTION}

The Brazilian Atlantic Forest is considered one of the three most threatened ecosystems on Earth, and is also a biodiversity hot spot (Myers et al. 2000). The state of São Paulo, SE Brazil, had more than $82 \%$ of its area covered by forest, but today the remnants account for only $7 \%$ of this original distribution (SOS Mata Atlântica 1998). In the Dense Ombrophylous Forest (IBGE, 1992) from southern and southeastern Brazil, the most common angiosperm families in terms of number of species, including both low and high altitudes, (i.e. below and above $700 \mathrm{~m}$ high, respectively) are: Myrtaceae, Leguminosae, Rubiaceae, Melastomataceae, Lauraceae, Sapotaceae, Euphorbiaceae, Moraceae and Annonaceae (Oliveira Filho \& Fontes 2000).

Mycorrhiza are defined by Allen (1991) as a mutualistic symbiosis between plant and fungus localized in a root or root-like structure, in which energy moves primarily from plant to fungus and inorganic resources move from fungus to plant. At least seven different types of mycorrhizal associations have been recognized, involving different groups of fungi and host plants and distinct root morphology patterns. Arbuscular mycorrhiza (AM) are associations where Zygomycete fungi in the Glomales produce arbuscules, hyphae and vesicles within roots. Spores are formed in soil or roots. These associations are defined by the presence of arbuscules (Sylvia et al. 1998). Arbuscular mycorrhizal fungi (AMF) are frequently found in association with native species in natural and agricultural ecosystems (Jakobsen 1994). The occurrence of AMF favours the establishment, survival and growth of host and non-host plants due to enhancement of water and mineral nutrients absorption, especially P, N, Zn and Cu (Evans \& Miller 1990, Marschner \& Dell 1994, Clark \& Zeto 2000). They also contribute to a more efficient mineral cycling, soil stabilization and also provide an important nutrient conserving mechanism (Redhead 1980, Janos 1984). AMF is of great interest to forest ecology because of the potential influence on ecosystem process and the role in determining plant diversity in natural communities (Francis \& Read, 1994, Sanders et al. 1996, Heijden et al. 1998). Mycorrhizal fungi are crucial to the success of rehabilitation and re-vegetation programs of degraded land (Janos 1995, Schmidt et al. 1999, Wali 1999). In spite of the fact that there is little information of AMF in natural ecosystems, a typical estimate of diversity on the basis of spore counts ranges between 5-20 different species in a community (Sanders et al. 1996).

In the Mata Atlântica (including Ombrophylous, Seasonal and Mixed forests; Joly et al. 1999; Oliveira Filho \& Fontes 2000), where the soil is normally sandy, acidic and very poor, information about mycorrhiza occurrence and diversity are limited (Bononi \& Trufem 1983, Trufem 1990, Trufem \& Viriato 1990, Siqueira et al. 1998, Zangaro et al. 2000, Santos 2001). The low soil fertility and limited P avail- ability favour the symbiotic association because the AM fungi may increase the P supply for plants (Clark \& Zeto 2000). Janos (1980a) found that the mycorrhizal association enhanced the growth of 23 species from a tropical forest in Costa Rica. Janos (1980a,b, 1995) suggested that the dependence on mycorrhizal association is higher in late successional species in the tropical forests of Costa Rica, and that early successional species are non-mycotrophic or facultatively mycotrophic (mycotrophy - dependency on the symbiosis for optimal growth; mycothophic species are dependent upon symbiosis). On the other hand, Siqueira et al. (1998) reported that pioneer species from southeast Brazil showed high susceptibility to infection and colonization of AM fungi. Zangaro et al. (2000) showed that mycorrhizal dependence is higher in early successional species, and much lower in late successional species from south Brazil.

The main objectives of this study were to characterize the colonization and species diversity of arbuscular mycorrihzal fungi (AMF) in the rhizosphere of tree species that occur in an Atlantic forest chronosequence on a eutrophic soil with low $\mathrm{P}$ content, and near neutral $\mathrm{pH}$, in the southeast of São Paulo State, Brazil. This study is a contribution to the knowledge about Atlantic Forest biodiversity and regeneration, and to the development of a forest recovery model to support rehabilitation and management actions.

\section{MATERIAL AND METHODS}

2.1 Study Site - The study area is located in São Paulo State, southeastern of Brazil, at the Ribeira de Iguape watershed, inside of Tourist State Park of the High Ribeira Parque Estadual Turístico do Alto Ribeira-PETAR, (2431'43" S and 48 41'09" W), approximately 350 km southwest from São Paulo City. Regional climate is tropical hyper humid without a dry season with mean annual precipitation around $1.800 \mathrm{~mm}$, well distributed through the year $(34 \%$ in the summer and $17 \%$ in the winter) and mean annual temperature between $17-19^{\circ} \mathrm{C}$ (Gutjahr 1993). The study site is located at 500-600 m above sea level on a calcareous substrate (figure 1), classified as Cambisols associated with Chernozems (Camargo et al. 1986, FAO-ISRIC-ISSS 1998). The soil at the study area is characterized as eutrophic with low $\mathrm{P}$ content and near neutral $\mathrm{pH}$. A more detailed description of the study area is presented in Aidar et al. (2001).

2.2 Forest survey and tree species characterization The phytosociological survey was carried out in three adjacent areas which present different time intervals following abandoning of slash-and-burn agriculture: Early Phase (EP) with 15 years; Mid Phase (MP) with 25 years; and Late Phase (LP) with more than 36 years without clear-cut (Figure 2). The detailed phytosociological inventory is presented 


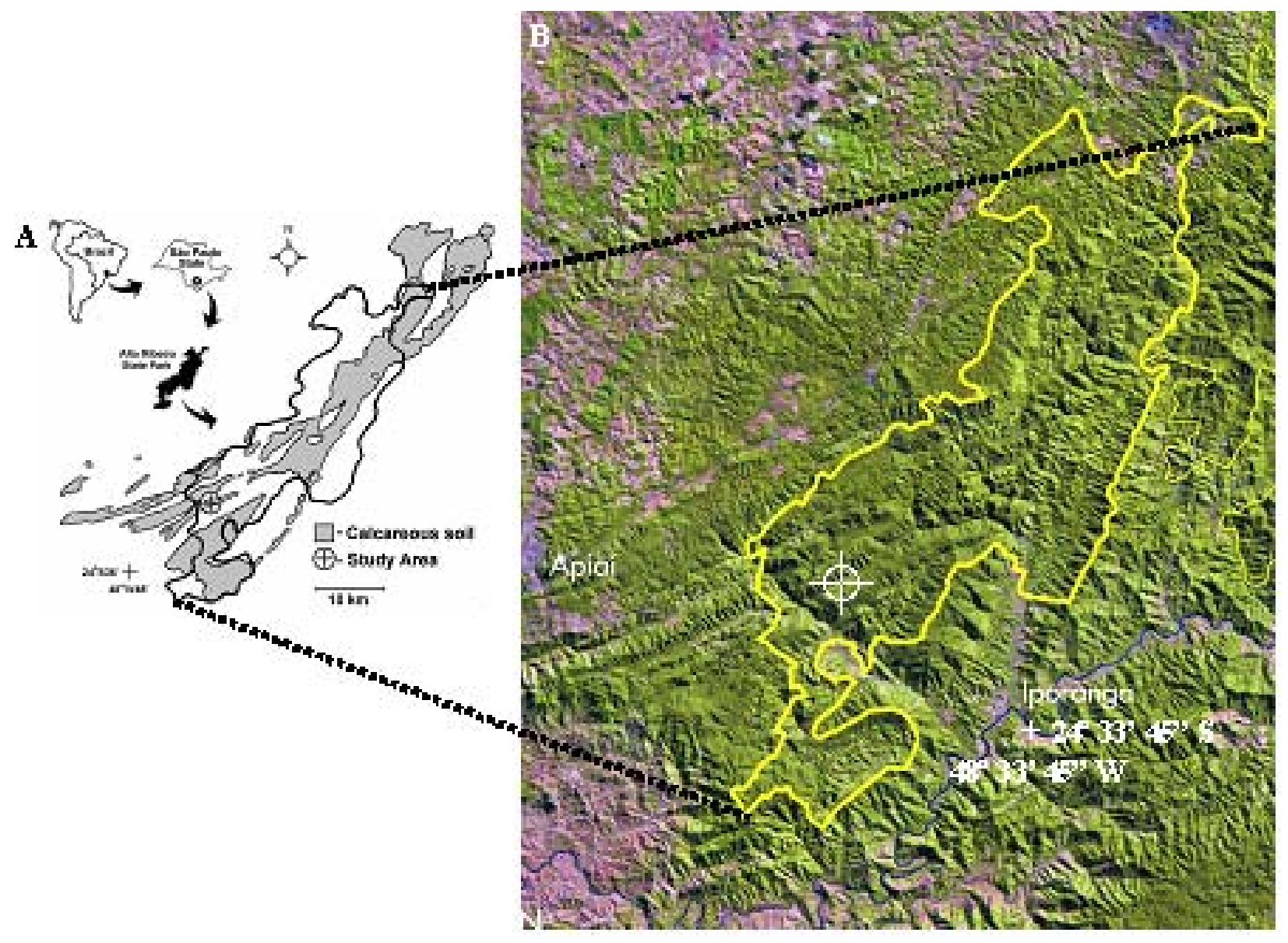

Figure 1. A. Study site localization (circle) and occurrence of the calcareous soil; B. Satellite image of PETAR - Tourist State Park of the High Ribeira Valley (border in yellow) showing the Mountains of the Serra de Paranapiacaba, Ribeira River (in blue) and the cities of Iporanga and Apiai; study site indicated by a circle. 

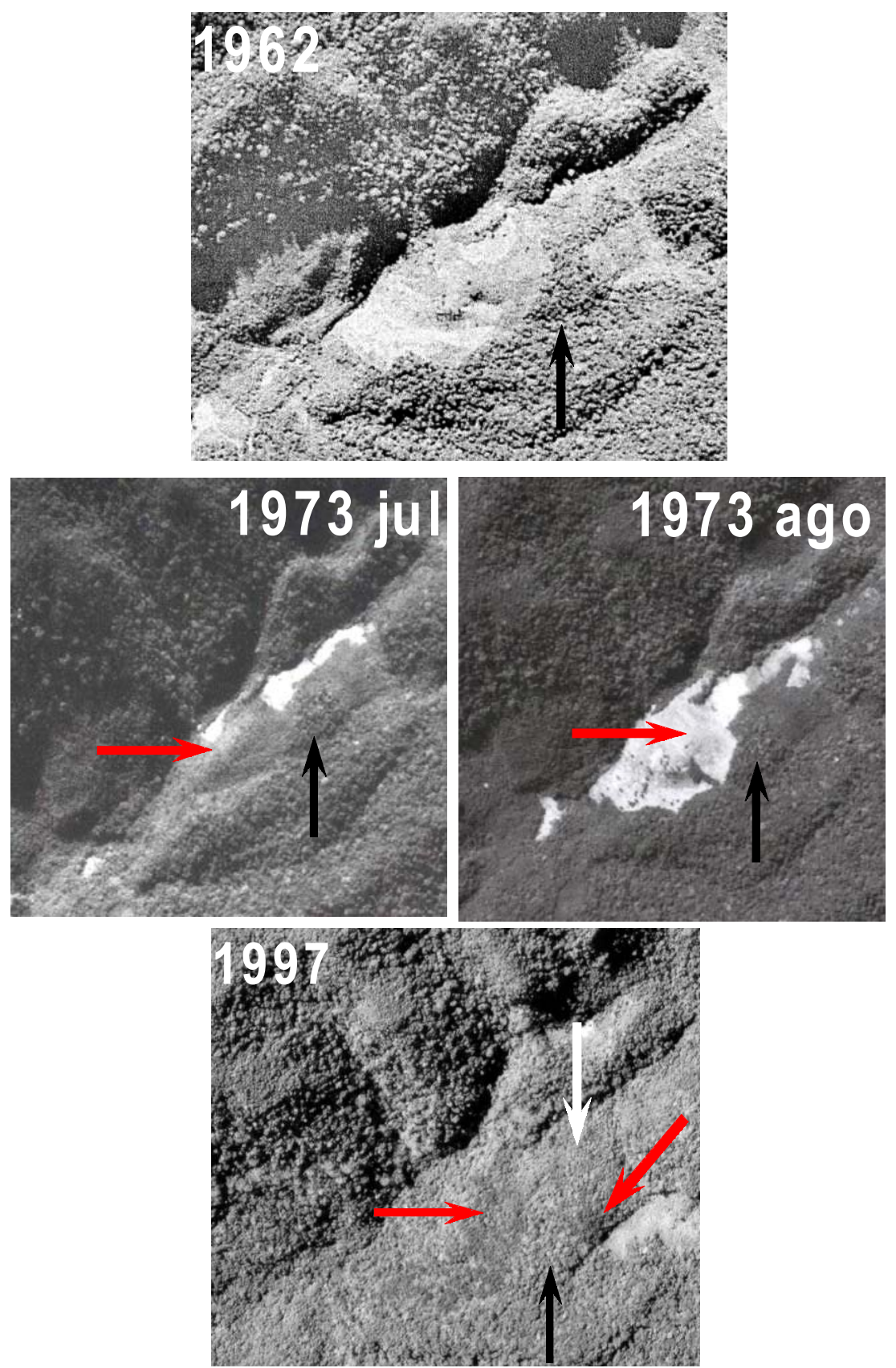

Figure 2. Historical series of aerial photographs showing the evolution of the vegetation coverage in the study area: 1962 - Aerial photo showing a forested area (original scale 1:25.000), which remains uncut (black arrow) throughout the time comprehended by our study; 1973 - Aerial photos from two different periods in 1973 (July and August, respectively; original scale 1:25.000) showing a forest fragment cut (red arrow) and the uncut fragment (black arrow). 1997 - Aerial photo showing the successional phases inventoried (original scale

1:35.000): white arrow - phase I (15 years after abandonment); red arrows indicate regeneration areas dominated by Piptadenia gonoacantha, phase II (25 years); black arrow - phase III (36+ years). (Adapted from Aidar et al. 2001). 


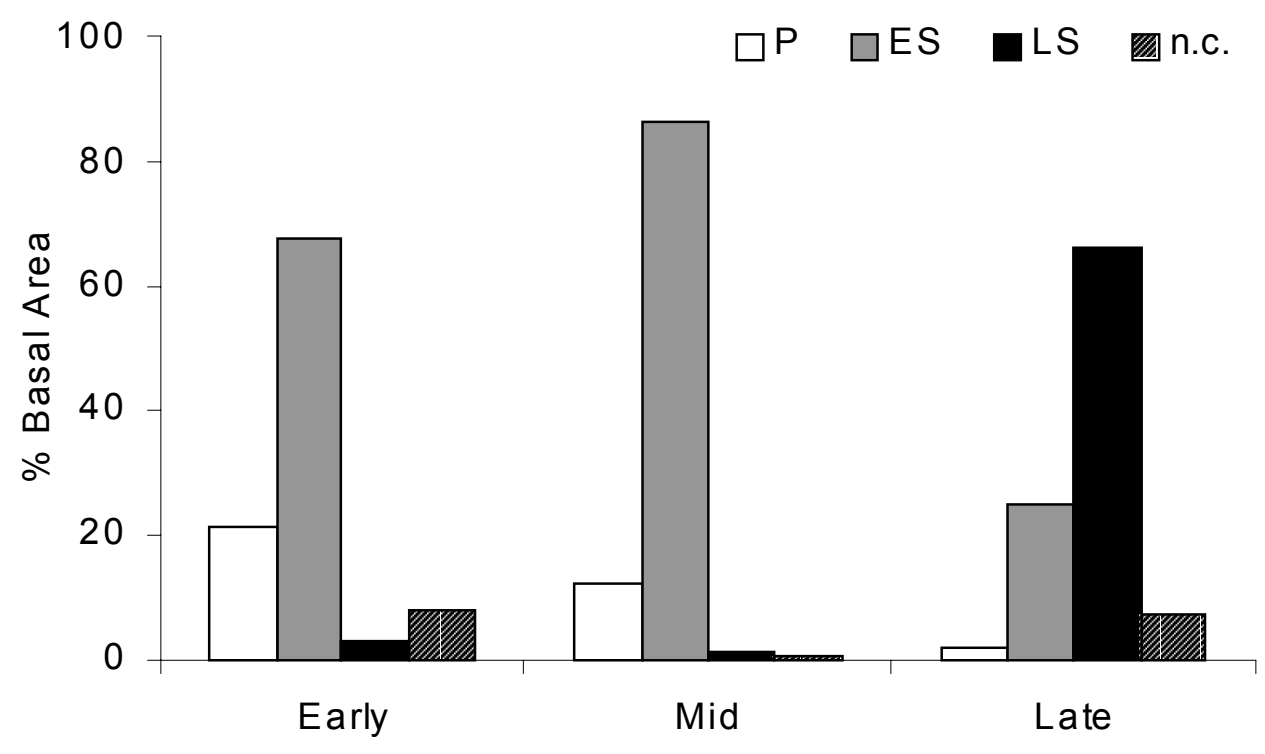

Figure 3. Distribution of relative basal area of the regeneration strategies guilds (sum of relative basal area of all species in each guild) in the successional phases of an Atlantic Forest chronosequence: Early - early successional phase (15 years after abandonment of crop field); Mid - mid successional phase (25 years); and Late - late successional phase (36+ years); P - pioneer species; ES - early secondary species; LS - late secondary specis; and n.c. - species not classified.

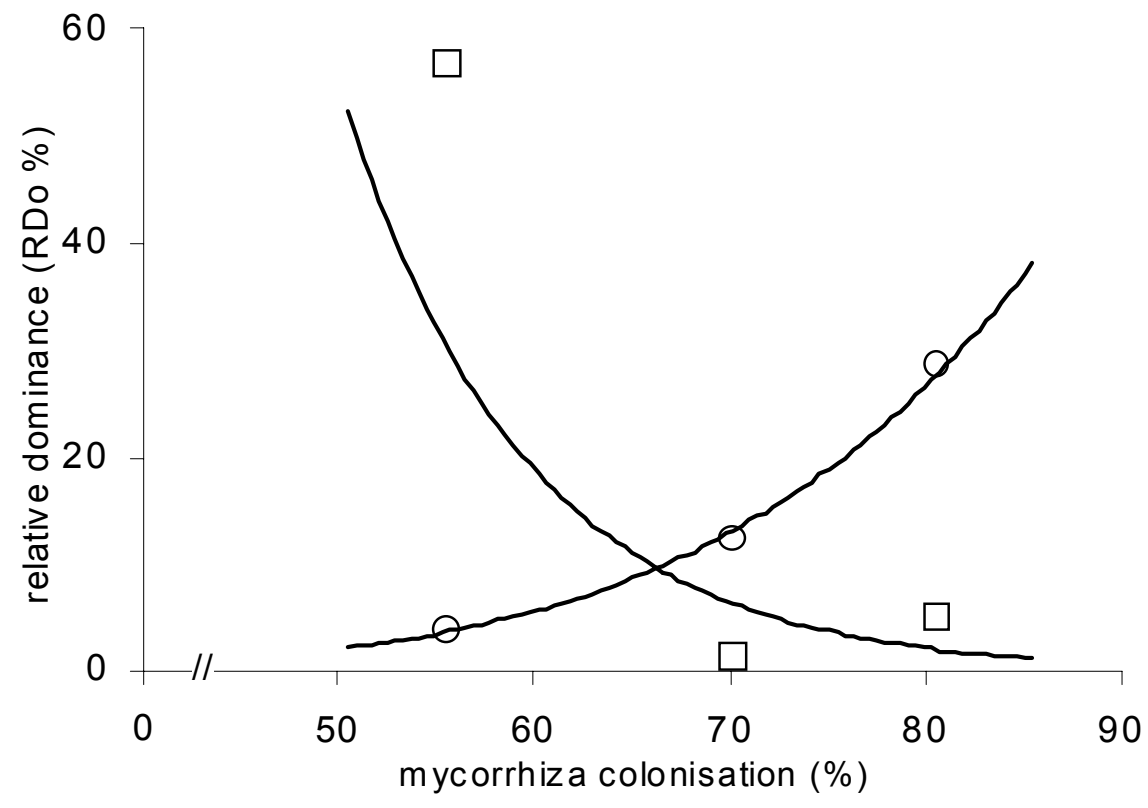

Figure 4. Correlation between mycorrhiza colonization (\%) and regeneration strategies occurrence (relative dominance RDo \%) in an Atlantic Forest chronosequence; Pioneer species - open circle; exponential pattern, $r=0.999, p<0.01$; Late secondary species - open square; exponential pattern, $r=-0.993, p<0.05$. 


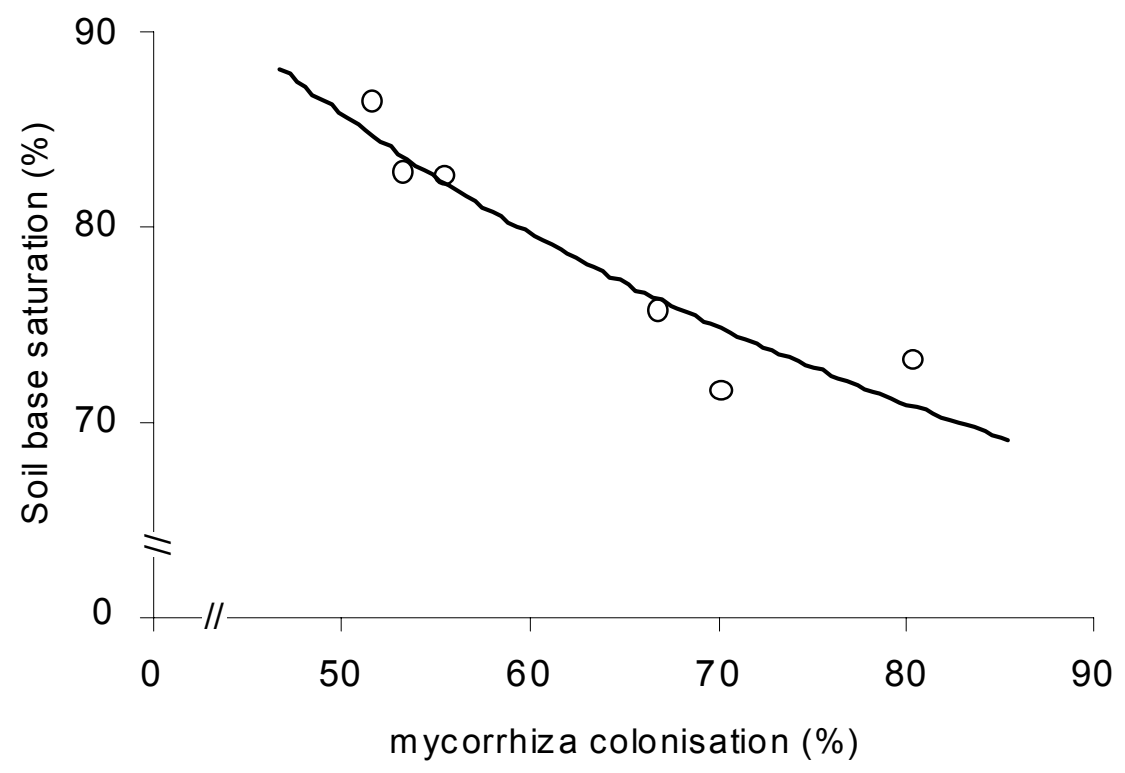

Figure 5. Correlation between mycorrhiza colonization (\%) and soil base saturation (\%) in an Atlantic Forest chronosequence; power pattern, $r=-0.967, p<0.05$.

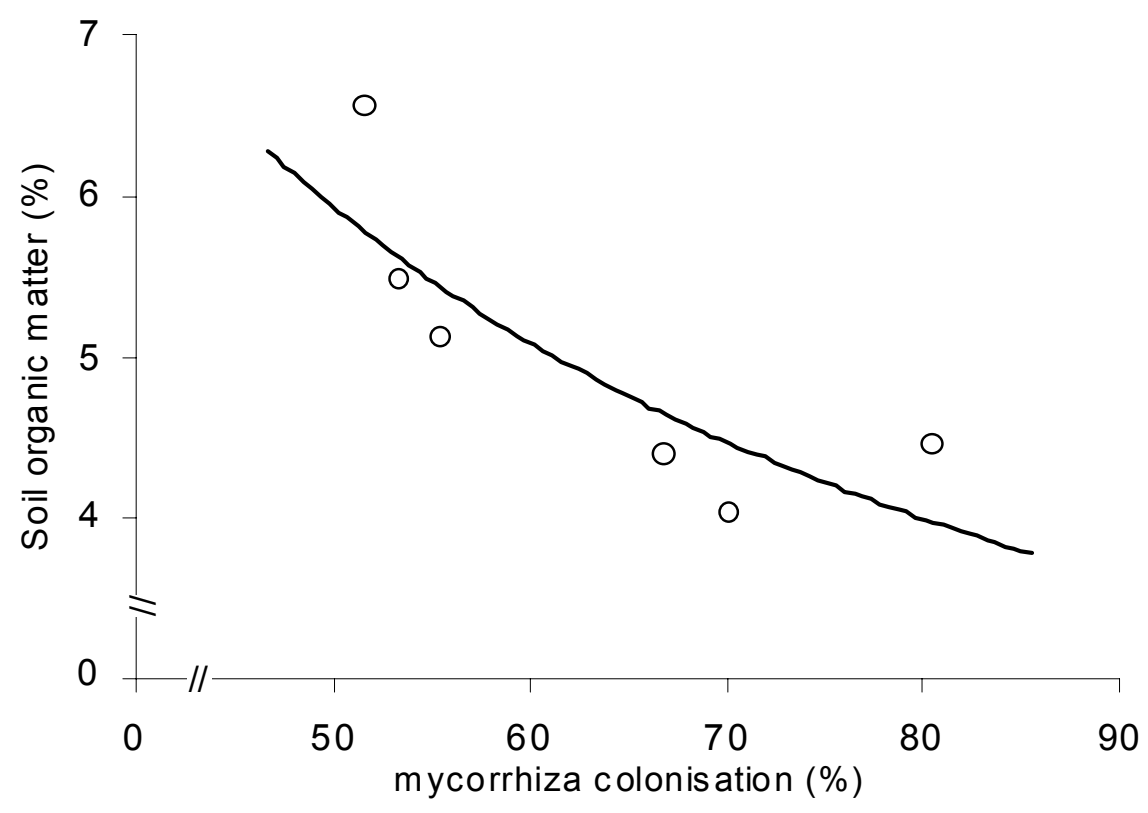

Figure 6. Correlation between mycorrhiza colonization (\%) and soil organic matter (\%) in an Atlantic Forest chronosequence; exponential pattern, $r=-0.861, p<0.05$. 
Table 1 - Mycorrhiza occurrence in roots of tree species in an Atlantic Forest chronosequence. $N$ - number of samples; values represent average with standard deviation in parenthesis; winter - less wet season; summer - wet season; different letters indicate significance for ANOVA and post hoc or two-sample $\mathrm{t}$ test, $p<0.05$; within column - A; within row - a. Early - early successional phase (15 years after abandonment of crop field); Mid - mid successional phase (25 years); and Late - late successional phase (36+ years)

\begin{tabular}{lcccc}
\hline & Phase & $\mathrm{N}$ & winter & summer \\
\hline & Early & 8 & $80.5(7.4)^{\mathrm{Aa}}$ & $53.3(12.3)^{\mathrm{Ab}}$ \\
colonization (\%) & Mid & 7 & $70.2(5.8)^{\mathrm{Ba}}$ & $72.8(11.7)^{\mathrm{Aa}}$ \\
& & & & \\
& Late & 9 & $55.3(12.5)^{\mathrm{Ca}}$ & $46.6(24.7)^{\mathrm{Aa}}$ \\
\hline
\end{tabular}

Table 2. Arbuscular mycorrhizal fungi species identification and spore occurrence in soil samples from an Atlantic Forest chronosequence. Early - early successional phase (15 years after abandonment of crop field); Mid - mid successional phase (25 years); and Late - late successional phase (36+ years); Number of soil samples (100 g): 8 for Early; 7 for Mid; and 9 for Late; winter - less wet season; summer wet season; Symbol key: $+<1$ average spore number.$g^{-1}$ soil; ++1 to $5 ;+++5$ to $10 ;++++>10 ;-$ not present. More detailed information about successional phases is presented in Aidar et al. 2001.

\begin{tabular}{|c|c|c|c|c|c|c|}
\hline \multirow[t]{2}{*}{ AM species } & \multicolumn{3}{|c|}{ winter } & \multicolumn{3}{|c|}{ sum m er } \\
\hline & Ea rly & M id & Late & Ea rly & M id & Late \\
\hline Acaulospora aff. elegans & - & - & - & + & - & - \\
\hline Acaulospora fo ve ata & + & + & - & + & + & + \\
\hline A c a ulo spora m ellea & - & - & - & - & + & - \\
\hline Acaulospora morrowiae & - & - & - & - & + & + \\
\hline Acaulo spora re hm ii & + & + & + & - & + & - \\
\hline Acaulospora scrobicula ta & + & + & - & + & + & + \\
\hline Ac aulospora sp. 1 & - & - & - & - & + & - \\
\hline A caulospora sp. 2 & - & - & - & - & + & - \\
\hline Acaulospora sp. 3 & - & - & - & - & - & + \\
\hline Acaulospora sp. 4 & - & - & - & - & - & ++ \\
\hline Acaulospora sp. 5 & - & + & - & - & - & - \\
\hline Acaulospora spinosa & + & - & - & ++ & - & ++ \\
\hline Ac a ulo spora tuberculata & - & + & + & - & + & + \\
\hline Arque ospora lep to ticha & - & - & + & + & - & - \\
\hline Entrophospora infrequens & + & - & - & - & - & - \\
\hline Gigaspora aff. decipiens & + & - & - & - & - & - \\
\hline Glom us aff. aggregatum & - & - & - & - & + & - \\
\hline Glom us aff. claroide um & - & - & - & - & + & - \\
\hline Glom us aff. microcarpum & - & - & - & - & - & ++ \\
\hline Glom us aff. monosporum & + & - & - & - & - & - \\
\hline Glom us aff. rubiform is & - & - & - & - & - & + \\
\hline Glom us aff. versiforme & - & - & - & ++ & ++ & ++ \\
\hline Glom us etunicatum & ++ & + & ++ & ++ & +++ & ++ \\
\hline Glom us geosporum & + & + & + & + & + & + \\
\hline Glom us heterosporum & - & - & - & +++ & +++ & ++++ \\
\hline G lom us inverm aium & - & - & - & + & + & +++ \\
\hline Glom us macrocarpum & ++ & - & + & ++ & +++ & ++++ \\
\hline Scutellospora calospora & + & - & - & - & - & + \\
\hline Scutellospora sp. 1 & - & - & - & - & - & + \\
\hline
\end{tabular}

http://www.biotaneotropica.org.br 
Table 3 - Arbuscular mycorrhizal fungi diversity indexes in an Atlantic Forest chronosequence: Shannon-Wiver index (H'); Pielou index (J'); and Margalef index (R). Early - early successional phase (15 years after abandonment of crop field); Mid - mid successional phase (25 years); and Late - late successional phase (36+ years); Number of soil samples (100 g): 8 for Early; 7 for Mid; and 9 for Late; winter - less wet season; summer - wet season.

\begin{tabular}{|c|c|c|c|c|c|c|c|c|c|}
\hline \multirow[t]{2}{*}{ Index } & \multicolumn{4}{|c|}{ winter } & \multicolumn{4}{|c|}{ summer } & \multirow[t]{2}{*}{ Total } \\
\hline & Early & Mid & Late & to tal & Early & Mid & Late & to tal & \\
\hline $\mathrm{H}^{\prime}$ & 1.70 & 1.69 & 1.10 & 1.68 & 1.91 & 1.98 & 1.96 & 2.14 & 2.31 \\
\hline$J^{\prime}$ & 0.71 & 0.70 & 0.46 & 0.70 & 0.80 & 0.71 & 0.69 & 0.66 & 0.97 \\
\hline $\mathrm{R}$ & 2.39 & 1.91 & 1.24 & 2.57 & 1.85 & 2.68 & 2.53 & 3.45 & 4.12 \\
\hline
\end{tabular}

in Aidar et al. (2001). The Basal Area was used as the index to assess relative space occupation and is estimated by the relative basal area of all individuals belonging to one species or family, and was calculated by converting circumference at breast height to basal area $\left(\mathrm{cm}^{2}\right)$. The classification used to distinguish guilds of tree regeneration strategies is based in Gandolfi et al. (1995): a) Pioneer Species - are specialized to occupy big gaps, require light for germination and growth, and are shade intolerant; b) early secondary species - are specialized to occupy medium size gaps, tend to germinate in shade conditions, but require higher light levels for growth to reach maturity and/or canopy; c) late secondary species - specialized to occupy small gaps and understorey, do not necessarily require light increment for germination and development, and can either remain in the understorey, or reach the canopy. Some species could not be classified and were listed as "not classified". The successional status of individual tree species was defined by the analysis of a set of characteristics, such as seed size, germination, seedling establishment, growth rate, height and diameter, etc. gathered by personal observation and from available literature on their morphological features and ecological preferences (Reitz 1966, Reitz et al. 1978a,b, Inoue et al. 1984, Lorenzi 1992, 1998, Leitão Filho et al. 1993, Gandolfi et al. 1995, Gandolfi 2000; Godoy 2001). When species classification differed among authors, we classified the species according the behaviour presented in the study area, using their relative importance (relative basal area) and nitrogen use strategies in the successional phases as the main descriptors (Aidar et al. 2003). When information for a particular species could not be verified satisfactorily due to a lack of bibliographical information and/or a low occurrence in the study area, it was treated as a "not classified species". The Basal Area for each regeneration guild along the forest succession was calculated as the sum of species belonging to each group, and was presented as a percentage of total basal area obtained for the respective successional phase.
2.3 Evaluation of mycorrhizal colonization and communities of AMF spores - A core collector $\left(10 \mathrm{~cm}^{3}\right)$ was used to collect the roots samples, which were taken at $10 \mathrm{~cm}$ deep in 8 sites at EP, 7 sites at MP and 9 sites at LP. The mycorrhizal colonization was assessed in July 1997 (dry period) and in December 1997 (wet period) in roots with diameter ${ }^{3} 2$ mm clarified in $10 \% \mathrm{KOH}$ and $\mathrm{H}_{2} \mathrm{O}_{2}$, acidified with $\mathrm{HCl} 1 \%$, washed in running water and stained with $0.05 \%$ tryptan blue (Phillips \& Hayman, 1970). The colonization frequency, which means the sum of all mycorrhizal structures present on roots (arbuscules, vesicules, extra and intra-radical hyphae), was calculated as number of total intersections on $1 \mathrm{~g}$ FW of root cut into $1 \mathrm{~cm}$ long pieces, and scored over a lamina with $1 \mathrm{~cm}$ grid. In order to assess the specific composition of AM fungi associated to the rizosphere of the tree species, samples of $100 \mathrm{~g}$ from the soil were processed by wet sieving (Gerdemann \& Nicolson 1963) and sucrose centrifugation (Jenkins 1964) to extract the spores present, and these were counted on semi-permanent lamina with PVLG resin (Morton et al. 1992), and identified using the AM fungi identification manuals (Schenck \& Pérez 1988, Trufem 1990, Carrenho 1994, Carrenho \& Trufem 2001). Species richness and diversity indices were calculated in order to evaluate the differences among successional phases and seasons: Shannon (species diversity) index) $\mathrm{H}^{\prime}=-\mathrm{a}\left(\mathrm{N}_{\mathrm{i}} / \mathrm{N}\right)^{2} \ln \left(\mathrm{N}_{\mathrm{i}} / \mathrm{N}\right)$, where $\mathrm{Ni}=$ species spore number and $\mathrm{N}=$ total number of spores; Pielou index (eveness index) - J' = H'/Hmax, where: $\mathrm{Hmax}=\log _{2} \mathrm{~S}$, and $\mathrm{S}=$ number of species; Margalef (species richness $)$ index $-\mathrm{R}=(\mathrm{S}-1) / \mathrm{Ln} \mathrm{N}$, where $\mathrm{N}$ is the total number of spores.

\section{RESULTS}

The 82 identified tree species in the forest succession were referred to ecological guilds: 8 species belong to the pioneer guild ( $9.8 \%$ of the total species), 18 to the early secondary guild (22\%), 32 to the late secondary guild (39\%) and 24 species were not classified (29\%) (Annex). This clas- 
sification was also used to evaluate the distribution of regeneration guilds in the different successional phases (Figure 3). The dominance of regeneration strategies along successional phases clearly indicates the decrease in abundance of pioneer species and an increase of late secondary species. Early secondary species increased in abundance in the mid phase, and declined in the late phase.

Only AMF was found in the root samples of tree species occurring at the study site. The mycorrhizal colonization showed a significant $(\mathrm{p}<0.05)$ decrease as succession progresses, with the highest value for the early phase and the lowest for the late phase in the less wet season (winter). In the wet season, there was high intrasite variation, but no significant differences $(\mathrm{P}<0.05)$ between sites was found (table 1). The mycorrhizal colonization was well correlated with the increase of pioneer species along succession $(r=0.999 ; p<0.01)$, and was negatively correlated with late secondary species occurrence along the succession ( $\mathrm{r}=-0.927 ; \mathrm{p}<0.05)$ during dry season (Figure 4$)$, but showed no clear pattern during the wet season and showed no correlation with Early secondary species (data not shown). Mycorrhizal colonization were also negatively correlated with soil parameters along successional phases and seasons, Soil Base saturation $(\%)(r=-0.967 ; \mathrm{p}<0.05)($ Figure 5) and Soil Organic Matter content $(\%)(\mathrm{r}=-0.861 ; \mathrm{p}<$ 0.05) (Figure 6).

The AMF taxonomic analysis indicated 29 taxa belonging to the Glomales (Zygomycota), of which 23 were identified at the species level, and six only identified at the generic level (Table 2). Spore occurrence (total number of spores $=1836)$ showed a clear seasonal pattern, with ca. $90 \%$ spores found in the wet season $(\mathrm{EP}=48.3 \%$; $\mathrm{MP}=23.0$ $\%$; and LP $=18.6 \%$ of the total spore number). A high number of spores (ca. 34\% of total spore number) that could not be identified occurred also during the wet season (ca. 95\% unidentified spores). The genus Acaulospora showed the highest species diversity accounting for more than $56 \%$ of the species identified (13 species), and comprising $16 \%$ of total spore sample. The genus Glomus also showed high diversity, with around of $48 \%$ of identified species (11 species), but with the highest spore number, accounting for $57 \%$ of the total spores occurring in the rizosphere. The species Glomus heterosporum and G. macrocarpum which occurred only in the samples taken in the wet period, represented $19 \%$ and $11 \%$ of the total spore number, respectively. The species $G$. etunicatum occurred during the dry and the wet periods, and accounted for $10 \%$ of total spore number (Table 2). The total spore density was 38.3 spores $100 \mathrm{~g}^{-1}$ soil, and the spore density for the wet and dry seasons, respectively, were 68.7 spores $100 \mathrm{~g}^{-1}$ soil and 7.8 spores $100 \mathrm{~g}^{-1}$ soil. The richness index (R) indicates higher values for samples taken in the wet period, except for the EP. In general, the wet period showed higher values for spore number and species richness. The same pattern was ob- served for the species diversity (H'). The evenness index ( $\mathrm{J}$ ') indicates that higher species dominance occurred in the LP, especially during the dry period when spore numbers were lower (Table 3).

\section{DISCUSSION}

The species composition along the forest succession phases at the study site, and their classification into ecological groups, indicates the dominance of pioneer and early secondary species in the initial succession (EP and MP), and a clear dominance of late secondary species in the LP. Considering the inventory as a whole, Leguminosae was the most important family, followed by Myrsinaceae, Myrtaceae, Annonaceae, Lauraceae, Rubiaceae and Melastomataceae, all of these have been recognised as mycorrhizal taxa (Trappe 1987).

The results obtained with respect to mycorrhizal colonization supported the conclusions of Zangaro et al. (2000) and Siqueira et al. (1998) for native species from south and southeastern Brazil, where tree species dependency on AMF decreases during succession: early stages are dominated by pioneer species which are obligatory mycotrophic, and which exhibit high colonization rates; medium stages are dominated by early secondary species which are either obligatory and facultative mycotrophic taxa; and advanced stages are dominated by late secondary species which are facultatively mycotrophic, or non-mycotrophic.

The seasonal dynamics of root colonization by AMF are well documented (Allen et al. 1998). Some studies showed higher colonization levels in the wet season while others showed higher percentages in the dry season. This study showed decrease in colonization in the EP during the wet season, which can be a response to the increased availability of nutrients, due more soil humidity and more intense microbial activity in the organic matter at this time. Negative correlations were observed between soil base saturation and root colonization (figure 4), and organic matter and root colonization (figure 5) suggesting that mycohrrizal dependence decreases with increasing soil fertility.

Spore abundance and the number of species found in the study area are similar to those of other studies in the Mata Atlântica of São Paulo State (Trufem 1990; Trufem \& Viriato 1990; Santos 2001), and higher than the values reported for forest areas suffering from air pollution (Trufem \& Viriato 1990). The genus Glomus showed the highest number of spores and a high diversity index, corroborating data found by Silveira (1998) who suggested that this genus prefers soils with a higher $\mathrm{pH}$ than the acidic soils which are typical of the Atlantic Forest.

G.macrocarpum, G.etunicatum, G.heterosporum e $G$. aff. versiforme showed higher frequency and abundance, suggesting broader range of ecological adaptation in relation to floristic composition and soil characteristics. 
G.macrocarpum and G.etunicatum have been reported as dominant species in other studies conducted in the Mata Atlântica. Santos (2001) found that G. macrocarpum dominated (37\% of total spore number) in a Mature Atlantic Forest during the wet season, while G. etunicatum dominated (26\% total spores) during the dry season. In the secondary forest, this author found $G$. marcocarpum as a dominant species in both seasons; both species were present in all samples analyzed. Trufem (1990) found G. macrocarpum as the dominant species in all samples analyzed, representing $38 \%$ of the total spore number.

A comparison with other studies in the Mata Atlântica indicates a high number of common species: 7 species found in common with Trufem \& Viriato (1990), 11 species with Santos (2001) and 14 with Trufem (1990). A. foveata, A. scrobiculata, Gl. geosporum, Gl. macrocarpum, and $S$. calospora were found in all studies.

During the wet season, AMF communities in the three successional phases showed little variation in respect to the species occurrence and distribution, with EP and LP being very similar when richness, diversity and evenness are considered.

The results presented here suggest that mycorrhizal inoculation should be considered as a critical factor for the success of recuperation of regional forested ecosystems, and is of great importance to the development of methodology for ecosystem rehabilitation, including the globalchange scenarios (Rilling \& Allen, 1999). This aspect is even more important when considering this locally restricted Atlantic Forest successional pattern and the urgent necessity for rehabilitation of degraded lands inside and around the Tourist State Park of the High Ribeira-PETAR boundaries.

\section{ACKNOWLEDGEMENTS}

We thank our field workers, José da Mota, Eufrásio da Mota e Orlei Lopes, that made our sampling possible; Dra. Sandra F.B. Trufem, Instituto de Botânica de São Paulo, for the support in the mycorrhiza identification; the people from PETAR - Instituto Florestal for their permission to work in the Conservation Unit, in memorium Roberto Burgui. Carlos A. Joly was supported by a CNPq Productivity Fellowship (Processo 520334/99-0). We also thank Dr. Peter E. Gibbs for valuable comments on an earlier draft of the manuscript and for revising the English.

\section{BIBLIOGRAPHY}

AIDAR, M.P.M., GODOY, J.R.L., BERGMANN, J. \& JOLY, C.A. 2001. Atlantic Forest succession over calcareous soil - PETAR, SP. Rev. Bras. Bot. 24:455-469
AIDAR, M.P.M., SCHMIDT, S., MOSS, G., STEWART, G.R. \& JOLY, C.A. 2003. Nitrogen use strategies of neotropical rainforest trees in threatened Atlantic Forest. Plant Cell and Environ. 26:389-399

ALLEN, E.B., RINCON, E., ALLEN, M.F., PEREZ-JIMENEZ, A. \& HUANTE, P. 1998. Disturbance and seasonal dynamics of mycorrhizae in a Tropical Deciduous Forest in Mexico. Biotropica 30:261-274

ALLEN, M.F. 1991. The Ecology of Mycorrhizae. Cambridge Univ. Press, Cambridge, U.K. 196p.

BONONI, V.L.R. \& TRUFEM, S.F.B. 1983. Endomicorrizas vesículo-arbusculares do cerrado da Reserva Biológica de Mogi-Guaçu, SP. Rickia 10:55-84

CAMArGO, O.A., MONIZ, A.C., JORGE, J.A. \& VALADARES, J.M.A.S. 1986. Métodos de análise química, mineralógica e física de solos do Instituto Agronômico de Campinas. Boletim Técnico do Instituto Agronômico de Campinas 106, Campinas, SP. 94p.

CARRENHO, R. \& TRUFEM, S.F.B. 2001. Caracterização morfológica de esporos de fungos micorrízicos arbusculares isolados de solo cultivado com milho, na Reserva Biológica e Estação Experimental de Moji-Guaçu, São Paulo, Brasil. Hoehnea 28(3):191-208.

CARRENHO, R. 1994. Efeitos dos fungicidas sistêmicos Fosetil-Al e Metalaxil-Mancozeb sobre o desenvolvimento de fungos micorrízicos arbusculares naturalmente estabelecidos em rizosferas de Citrus sinensis L. Osbeck/C. limonia L. Rio Claro: Universidade Estadual Paulista. Dissertação 250p.

CLARK, R.B. \& ZETO, S.K. 2000. Mineral acquisition by arbuscular mycorrhizal plants. Jour. Pl. Nutr. 23: 867-902

EVANS, D.G. \& MILLER, M.H. 1990. The role of the external mycelial network in the effect of soil disturbance upon vesicular-arbuscular mycorrhizal colonization. New Phytol. 115:65-71

FAO-ISRIC-ISSS. 1998. World reference base for soil resources. World Soil Resources Reports 84. Rome. FAO, ISSS and ISRIC.

FRANCIS, R. \& READ, D.J. 1994. The contribuitions of mycorrhizal fungi to the determination of plant community structure. Plant and Soil 159:11-25

GANDOLFI, S. 2000 História Natural de uma Floresta Estacional Semidecidual no Município de Campinas. Tese de Doutorado.Universidade Estadual de Campinas. Campinas.

GANDOLFI, S., LEITÃO FILHO, H.F. \& BEZERRA, C.L.F. 1995. Levantamento florísitico e caráter sucessional das espécies arbustivo-arbóreas de uma Floresta Mesófila Semidecídua no município de Guarulhos. Rev. Bras. Biol. 55:753-767 
GERDEMANN, J. W. \& NICOLSON, T.H. 1963. Spores of mycorrhizal Endogone species extracted from soil by wet-sieving and decanting. Trans. Br. Mycol. Soc. 46:235244.

GODOY, J.R.L. 2001. Estrutura e composição específica da Mata Atlântica secundária de encosta sobre calcário e filito, no Parque Estadual Turístico do Alto Ribeira, Iporanga, SP. Dissertação de Mestrado, Universidade de São Paulo. São Paulo.

GUTJAHR, M.R. 1993. Critérios relacionados à compartimentação climática de Bacias Hidrográficas: A Bacia do Rio Ribeira de Iguape. Dissertação de Mestrado, FFLCCH/USP, SP.

HEIDJEN, M.G.A., KLIRONOMOS, J.N., URSIC, M., MOUTOGLIS, P.; STREITWOLF-ENGEL, R., BOLLER, T., WIEMKEN, A \& SANDERS, I.R. 1998. Mycorrhizal fungal diversity determines plant biodiversity, ecosystem variability and productivity. Nature 396:69-72.

IBGE. 1992. Manual Técnico da Vegetação Brasileira. Manuais Técnicos em Geociências v1. Instituto Brasileiro de Geografia e Estatística, Rio de Janeiro. Brasil. 92p.

INOUE, M.T., RODERJAN, C.V. \& KUNIYOSHI, Y.S. 1984. Projeto madeira do Paraná. FUPEF, Curitiba, Paraná.

JAKOBSEN, I. 1994.Research approaches to study the functioning of vesicular-arbuscular mycorrhizas in the field. In: Management of Mycorrhizas in agriculture, horticulture and forestry (Robson,A.D., Abbot,L.K. \& Malaczuk,N. eds.) Kluwer Ac.Publ. Dordrecht. p.141-147

JANOS, D.P. 1980a. Vesicular-arbuscular mycorrhizae affect lowland tropical rain forest plant growth. Ecology 61:151162

JANOS, D.P. 1980b. Mycorrhizae influence tropical succession. Biotropica 12:56-64

JANOS, D.P. 1984. Methods for vesicular arbuscular mycorrhiza research in lowland wet tropics. In: Medina, E.; Mooney, H.A. \& Vazquez-Yanes, C. (eds.). Physiological ecology of plants of the wet tropics, Tasks for Vegetation Science 12, Junk: The Hague. p. 173-187.

JANOS, D.P. 1995. Mycorrhizas, succession and the rehabilitation of deforested lands in the humid tropics. In: Fungi and environmental change. (Frankland, J.C., Magan, N. \& Gadd, G.M., eds.) p. 276-282

JENKINS, W.R. 1964. A rapid centrifugal-flotation technique for separating nematodes from soil. Plant Disease Reporter 48:692.

JOLY, C.A., AIDAR, M.P.M., KLINK, C.A., MCGRATH, D.G., MOREIRA, A.G., MOUTINHO, P., NEPSTAD, D.C., OLIVEIRA, A.A., POTT, A., RODAL, M.J.N. \& SAMPAIO, E.V.S.B. (1999) Evolution of the Brazilian phytogeography classification systems: implications for biodiverisity conservation. Ciên. Cult. 51:331-348.
LEITÃO FILHO, H.F., PAGANO, S.N., CESAR, O., TIMONI, J.L. \& RUEDA, J.J. 1993. Ecologia da Mata Atlântica em Cubatão. Ed. Universidade Estadual Paulista e Ed. Universidade de São Paulo. São Paulo.

LORENZI, H. 1992. Árvores brasileiras. Manual de Identificação e cultivo de plantas arbóreas do Brasil. Ed. Plantarum. Nova Odessa. São Paulo.

LORENZI, H. 1998. Árvores brasileiras. Manual de Identificação e cultivo de plantas arbóreas do Brasil. Vol 2. Ed. Plantarum. Nova Odessa. São Paulo.

MARSCHNER, H. \& DELL, B. 1994. Nutrient uptake in mycorrhizal symbiosis. Plant and Soil 159:89-102

MORTON, J.B., BENTIVENGA, S.P., WHEELER, W.W. 1993. Germ plasm in the International Collection of Arbuscular and Vesicular-Arbuscular Mycorrhizal Fungi (INVAM) and procedures for culture development, documentation and storage. Mycotaxon 48:491-528. (INVAM http:/ /invam.caf.wvu.edu/)

MYERS, N., MITTERMEIER, R.A., MITTERMEIER, C.G., DA FONSECA, G.A.B. \& KENT, J. 2000. Biodiversity hotspots for conservation priorities. Nature 403:853-858

OLIVEIRA FILHO, A. \& FONTES, M.A. 2000. Patterns of Floristic Differentiation among Atlantic Forests in SouthEastern Brazil, and the Influence of Climate. Biotropica 32:793-810.

PHILLIPS, J.M. \& HAYMAN, D.S. 1970. Improved procedures for clearing roots for rapid assessment of infection. Transactions of British Mycological Society 55:158161.

REDHEAD, J.F. 1980. Mycorrhiza in natural tropical forests. In: Tropical Mycorrhiza Research. (Mikola, P. ed.). Clarendon Press. Oxford, p. 127-142.

REITZ, P.R. 1966-1984. Flora Ilustrada Catarinensis. CNPq/ IBDF/HBR. Itajaí, Brazil.

REITZ, P.R., KLEIN, R.M. \& REIS, A. 1978a. Projeto Madeira de Santa Catarina. Sellowia 30

REITZ, P.R., KLEIN, R.M. \& REIS, A. 1978b. Projeto Madeira do Rio Grande do Sul. Sellowia 34

RILLIG, M.C. \& ALLEN, M.F. 1999. What is the role of arbuscular mycorrhizal fungi in plant-to-ecosystem responses to elevated atmospheric $\mathrm{CO}_{2}$ ? Mycorrhiza 9:18.

SANDERS, I.R., CLAPP, J.I. \& WIEMKEN, A. 1996. The genetic diversity of arbuscular mycorrhizal fungi in natural ecosystems - a key to understanding the ecology and functioning of mycorrhizal symbiosis. New Phytol. 133:123-134.

SANTOS, I.S. 2001. Fungos micorrízicos arbusculares em ambientes de Mata Atlântica e de Eucaliptos na região de Entre Rios, Bahia. Dissertação de Mestrado, Departamento de Biologia (Botânica), Universidade Federal da Bahia. 69 p. 
SCHENCK, N.C. \& PÉREZ, Y, 1988. Maual for the identification of VA mycorrhizal fungi. $2^{\text {nd }}$. Ed. IFAS, Gainesville, University of Florida 241p.

SCHMIDT, S., STEWART, G.R., \& ASHWATH, N. 1999. Monitoring plant physiological characteristics to evaluate mine site revegetation: A case study from the wetdry tropics of northern Australia." Plant and Soil 215: 73-84.

SILVEIRA, A.P.D. 1998. Ecologia de fungos micorrízicos arbusculares. In: Melo, J.L. (ed.). Ecologia microbiana. Jaguariúna: EMBRAPA - CNPMA, cap. 2, p. 61-83.

SIQUEIRA, J.O., CARNEIRO, M.A.C., CURI, N., ROSADO, S.C.S. \& DAVIDE, A.C. 1998. Mycorrhizal colonization and mycotrophic growth of native woody species as related to successional groups in southeastern Brazil. For. Ecol. Manag. 107:241-252

SOS MATA ATLANTICA 1998. Evolução dos remanescentes florestais e ecossistemas associados do domínio Mata Atlântica no período 1990-1995. Fund. SOS Mata Atlântica/INPE.

SYLVIA, D., FUHRMANN, J., HARTEL, P.G. \& ZUBERER, D. 1998 Principles and applications of soil microbiology. Pearson Education - Prentice Hall. NJ. 550p.

TRAPPE, J.M. 1987. Phylogenetic and ecologic aspects of mycotrophy in angiosperms from an evolutionary standpoint. In: Safir, G.R. (ed.). Ecophysiology of VA mycorrhizal plants. Boca Raton: CRC Press, p.5-25.

TRUFEM, S.F.B. \& VIRIATO, A. 1990. Fungos micorrízicos vesiculo-arbusculares da Reserva Biológica do Alto da Serra de Paranapiacaba, São Paulo, Brasil. Rev. Bras. Bot. 13:49-53

TRUFEM, S.F.B. 1990. Aspectos ecológicos de fungos micorrízicos vesículo-arbusculares da mata tropical da Ilha do Cardoso, SP, Brasil. Acta Botânica Brasileira 4:3145

WALI, M.K. 1999. Ecological succession and the rehabilitation of disturbed terrestrial ecosystems. Plant and Soil 213: $195-220$.

ZANGARO FILHO, W., BONONI, V.L.R. \& TRUFEM, S.B. 2000. Mycorrhizal dependency, inoculum potential and habitat preference of native woody species in South Brazil. J. Trop. Ecol. 16:603-622

Title: Aspects of arbuscular mycorrhizal fungi in an Atlantic Forest chronosequence

Authors: Marcos P.M. Aidar, Rosilaine Carrenho, Carlos A. Joly

Biota Neotropica, Vol. 4 ( number 2 ): 2004

http://www.biotaneotropica.org.br/v4n2/pt/ abstract?article+BN02504022004

Date Received: $12 / 14 / 2004$

Revised: 06/30/2004

Accepted: 07/01/2004

ISSN 1676-0611 
Classification of tree species inventoried at PETAR, (SP) into successional groups: $\mathrm{P}$ - pioneer species; E - early secondary species; L - late secondary species; nc - not classified. (Adapted from Aidar et al. 2001).

\begin{tabular}{|c|c|c|}
\hline Species & Family & status \\
\hline Alchornea triplinervia (Spreng.) Müll. Arg. & Euphorbiaceae & E \\
\hline Allophyllus edulis (A. St. Hil.) Radlk. & Sapindaceae & $\mathrm{P}$ \\
\hline Alseis floribunda Schott & Rubiaceae & nc \\
\hline Aspidosperma polyneuron Muell. Arg. & Apocynaceae & $\mathrm{L}$ \\
\hline Aspidosperma ramiflorum Muell. Arg. & Apocynaceae & $\mathrm{L}$ \\
\hline Bathysa meridionalis Smith \& Downs & Rubiaceae & $\mathrm{L}$ \\
\hline Bauhinia forficata Link & Leguminosae & $\mathrm{P}$ \\
\hline Beilschmiedia cf. emarginata (Nees) Kosterm. & Lauraceae & nc \\
\hline Calyptranthes concinna DC. & Myrtaceae & nc \\
\hline Campomanesia guaviroba (DC) Kiaerskow & Myrtaceae & $\mathrm{E}$ \\
\hline Casearia sylvestris Sw. & Flacourtiaceae & $\mathrm{P}$ \\
\hline Cecropia glaziovi Snethlage & Cecropiaceae & $\mathrm{P}$ \\
\hline Cecropia pachystachya Trécul & Cecropiaceae & $\mathrm{P}$ \\
\hline Cedrela fissilis Vell. & Meliaceae & $\mathrm{L}$ \\
\hline Chrysophyllum inornatum Mart. & Sapotaceae & $\mathrm{L}$ \\
\hline Clethra scabra Pers. & Cletraceae & nc \\
\hline Cordia trichotoma (Vell.) Arráb. ex Steud. & Euphorbiaceae & nc \\
\hline Coussapoa microcarpa (Schott) Rizzini & Cecropiaceae & nc \\
\hline Cupania oblongifolia Mart. & Sapindaceae & nc \\
\hline Dalbergia frutescens (Vell.) Britton & Leguminosae & $\mathrm{L}$ \\
\hline Ecclinusa ramiflora Mart. & Sapotaceae & $\mathrm{L}$ \\
\hline Endlicheria paniculata (Spreng.) J.F. Macbr. & Lauraceae & $\mathrm{P}$ \\
\hline Eugenia cuprea (O. Berg) Mattos & Myrtaceae & $\mathrm{L}$ \\
\hline Eugenia florida DC. & Myrtaceae & nc \\
\hline Eugenia riedeliana $\mathrm{O}$. Berg & Myrtaceae & nc \\
\hline Euterpe edulis Mart. & Palmae & $\mathrm{L}$ \\
\hline Ficus $\mathrm{sp}$ & Moraceae & $\mathrm{L}$ \\
\hline Garcinia gardneriana (Planch. \& Triana) Zappi & Clusiaceae & nc \\
\hline Gomidesia tijucensis (Kiaersk.) D. Legrand & Myrtaceae & nc \\
\hline Guapira opposita (Vell.) Reitz & Nyctaginaceae & $\mathrm{E}$ \\
\hline Guarea macrophylla Vahl & Meliaceae & nc \\
\hline Guatteria nigrescens Mart. & Annonaceae & nc \\
\hline Heisteria silvianii Schwacke & Olacaceae & nc \\
\hline Hyeronima alchorneoides Allemao & Euphorbiaceae & $\mathrm{E}$ \\
\hline Hymenaea courbaril L. & Leguminosae & $\mathrm{L}$ \\
\hline Inga marginata Willd. & Leguminosae & $\mathrm{E}$ \\
\hline Leandra cf. mosenii Cogn. & Melastomataceae & nc \\
\hline Lonchocarpus sp & Leguminosae & $\mathrm{L}$ \\
\hline Machaerium nyctitans (Vell.) Benth. & Leguminosae & nc \\
\hline Machaerium stipitatum (DC.) Vogel & Leguminosae & nc \\
\hline Marlierea eugeniopsoides (D. Legrand \& Kausel) D. Legrand & Myrtaceae & nc \\
\hline
\end{tabular}




\begin{tabular}{|c|c|c|}
\hline Species & family & status \\
\hline Matayba elaeagnoides Radlk. & Annonaceae & $\mathrm{E}$ \\
\hline Matayba junglandifolia (Cambess.) Radlk. & Sapindaceae & $\mathrm{L}$ \\
\hline Maytenus cf. evonymoides Reisseck & Celastraceae & $\mathrm{L}$ \\
\hline Meliosma sellowii Urb. & Sabiaceae & $\mathrm{nc}$ \\
\hline Miconia cinnamomifolia (DC.) Naudin & Melastomataceae & $\mathrm{L}$ \\
\hline Miconia latecrenata Triana & Melastomataceae & $\mathrm{L}$ \\
\hline Myrceugenia myrcioides (Cambess.) O. Berg & Myrtaceae & $\mathrm{L}$ \\
\hline Myrcia cf. rostrata DC. & Myrtaceae & $\mathrm{E}$ \\
\hline Myrcia pubipetala Miq. & Myrtaceae & $\mathrm{L}$ \\
\hline Myrocarpus cf. frondosus Allemao & Leguminosae & $\mathrm{L}$ \\
\hline Myrsine coriacea (Sw.) R. Br. ex Roem. \& Schult. & Nyctaginaceae & $\mathrm{E}$ \\
\hline Myrsine umbellata Mart. & Myrsinaceae & $\mathrm{E}$ \\
\hline Nectandra megapotamica (Sprengel) Mez & Lauraceae & $\mathrm{L}$ \\
\hline Nectandra membranacea (Sw.) Griseb. & Lauraceae & $\mathrm{E}$ \\
\hline Nectandra oppositifolia Nees \& Mart. & Lauraceae & $\mathrm{L}$ \\
\hline Ocotea catharinensis $\mathrm{Mez}$ & Lauraceae & $\mathrm{L}$ \\
\hline Persea pyrifolia (Don) Spreng. & Lauraceae & $\mathrm{L}$ \\
\hline Piptadenia gonoacantha (Mart.) J.F. Macbr. & Leguminosae & $\mathrm{E}$ \\
\hline Piptadenia paniculata Benth. & Leguminosae & $\mathrm{E}$ \\
\hline Platymiscium floribundum Vogel & Leguminosae & $\mathrm{L}$ \\
\hline Pouteria psammophila (Mart.) Radlk. & Sapotaceae & nc \\
\hline Protium heptaphyllum (Aubl.) Marchand & Burseraceae & $\mathrm{L}$ \\
\hline Prunus myrtifolia (L.) Urb. & Rosaceae & $\mathrm{L}$ \\
\hline Psidium cattleyanum Sabine & Myrtaceae & nc \\
\hline Psychotria cf. carthagenensis Jacq. & Rubiaceae & $\mathrm{L}$ \\
\hline Pterocarpus cf. rohrii Vahl & Leguminosae & $\mathrm{L}$ \\
\hline Quiina glaziovii Engl. & Quiinaceae & $\mathrm{nc}$ \\
\hline Rollinia cf. rugulosa Schltdl. & Annonnaceae & $\mathrm{E}$ \\
\hline Rollinia sericea (R.E. Fr.) R.E. Fr. & Anonnaceae & $\mathrm{E}$ \\
\hline Roupala brasiliensis Klotzsch & Proteaceae & $\mathrm{L}$ \\
\hline Rudgea cf. jasminoides (Cham.) Müll. Arg. & Rubiaceae & $\mathrm{L}$ \\
\hline Savia dictyocarpa Müll. Arg. & Euphorbiaceae & nc \\
\hline Schizolobium parahyba (Vell.) S.F. Blake & Leguminosae & $\mathrm{E}$ \\
\hline Sorocea bonplandii (Baill.) W.C. Burger, Lanj. \& Wess. Boer & Cecropiaceae & nc \\
\hline Syagrus romanzoffiana (Cham.) Glassman & Palmae & $\mathrm{L}$ \\
\hline Symplocos laxiflora Benth. & Simplocaceae & $\mathrm{P}$ \\
\hline Tetrorchidium rubrivenium Poepp. & Euphorbiaceae & $\mathrm{E}$ \\
\hline Tibouchina pulchra (Cham.) Cogn. & Melastomataceae & $\mathrm{E}$ \\
\hline Trema micrantha (L.) Blume & Ulmaceae & $\mathrm{P}$ \\
\hline Trichilia lepidota Mart. & Meliaceae & $\mathrm{L}$ \\
\hline Verbesina $\mathrm{sp}$ & Asteraceae & $\mathrm{E}$ \\
\hline
\end{tabular}

